\title{
Catabolism of isonicotinate by Mycobacterium sp. INA1: extended description of the pathway and purification of the molybdoenzyme isonicotinate dehydrogenase
}

\author{
AnNette Kretzer, ${ }^{1}$ Kurt Frunzke ${ }^{2}$ and Jan R. Andreesen ${ }^{1 *}$ \\ ${ }^{1}$ Institut für Mikrobiologie der Universität Göttingen, Grisebachstrasse 8, D-37077 Göttingen, FRG \\ ${ }^{2}$ Lehrstuhl für Mikrobiologie der Universität Bayreuth, Postfach 101251, D-95440 Bayreuth, FRG
}

(Received 22 March 1993; revised 1 June 1993; accepted 18 June 1993)

\begin{abstract}
Catabolism of isonicotinate by Mycobacterium sp. INA1 has been shown to proceed via 2-hydroxyisonicotinate, 2,6-dihydroxyisonicotinate (citrazinate), citrazyl-CoA and 2,6-dioxopiperidine-4-carboxyl-CoA. An extended pathway involving propane-1,2,3-tricarboxylate as a further intermediate is presented in this paper. Propane-1,2,3tricarboxylate was oxidized stepwise to 2-oxoglutarate involving an oxidase, aconitase and isocitrate dehydrogenase. Isonicotinate dehydrogenase catalyses the first step of isonicotinate metabolism in Mycobacterium sp. INA1. The enzyme was purified to apparent homogeneity by a three-step procedure. Enrichment was accompanied by partial loss in specific activity. The native enzyme had a molecular mass of either $125 \mathrm{kDa}$ or $250 \mathrm{kDa}$, when estimated by native gradient PAGE or gel filtration, respectively. SDS-gel electrophoresis revealed three types of subunits with molecular masses of approximately 83, 31 and $19 \mathrm{kDa}$. N-Terminal amino acid sequences of all three subunits have been determined. Molybdenum, iron, acid-labile sulphur and FAD were present at molar ratios of $1,4,4,1$ per protomer $(125 \mathrm{kDa})$. The molybdenum-complexing cofactor was shown to be molybdopterin cytosine dinucleotide. Besides isonicotinate, only quinoline-4-carboxylate was found to be oxidized at appreciable rates.
\end{abstract}

\section{Introduction}

Bacterial metabolism of pyridine was known as early as 1914 , when it was tested for its sterilizing activity on soil and found to induce an unexpectedly high increase in bacterial cell number (Buddin, 1914). Whereas pyridine itself is attacked via a reductive step (Watson \& Cain, 1975), the bacterial catabolism of many substituted pyridine derivatives was found to involve hydroxylations of the heteroaromatic ring (for review, see Shukla, 1984). This is also true for quinoline (benzopyridine) (Grant \& Al-Najjar, 1976), isoquinoline (Aislabie et al., 1989) and some quinoline derivatives (Bauer \& Lingens, 1992; Schach et al., 1993). Due to the electron distribution, the pyridine ring permits nucleophilic attack in the orthoand para-positions (Sims \& O'Loughlin, 1989). There-

\footnotetext{
*Author for correspondence. Tel. +49551 393841; fax +49551 393793.

Abbreviations: camMCD, carboxamidomethylmolybdopterin cytosine dinucleotide; $\mathrm{DH}$, dehydrogenase; $\mathrm{MCD}$, molybdopterin cytosine dinucleotide; MGD, molybdopterin guanine dinucleotide.
}

fore, in the course of bacterial catabolism of pyridine derivatives, initial hydroxylations usually occur at these positions - with the ortho-position being favoured - and are generally catalysed by dehydrogenases. The incorporated hydroxyl group is derived from water (Hunt et al., 1958; Hirschberg \& Ensign, 1971; Pereira et al., 1988; Bray, 1988). These dehydrogenases which hydroxylate pyridine derivatives at the ortho-position form a structurally very similar group of molybdoenzymes. In contrast, meta-hydroxylations (which are not treated in this paper) are catalysed by oxygenases (Block \& Lingens, 1992). Meta-hydroxylations mostly represent the second (or third) hydroxylation so that the position is especially activated for an electrophilic attack by the electron supplying character of the existing hydroxyl substituent(s).

In the course of our research on molybdenumdependent bacterial transformations of heterocyclic substrates, we have looked at the degradation of isonicotinate (pyridine-4-carboxylate). The isolation of a mycobacterial species that metabolizes isonicotinate as the sole source of carbon, nitrogen, and energy, and some features of the catabolic pathway have already 
been described (Kretzer \& Andreesen, 1991). We now report on the detection of a propane-1,2,3-tricarboxylate oxidizing enzyme system and the purification and partial characterization of the first catabolic enzyme in the pathway, isonicotinate dehydrogenase. Only preliminary results have been available so far for an 'isonicotinate hydroxylase' that was partly purified from a Micrococcus sp. but not structurally characterized and that copurified with 2-hydroxyisonicotinate 'hydroxylase' activity (Gupta \& Shukla, 1979b). In Mycobacterium sp. INA1, the catabolic enzymes isonicotinate dehydrogenase and 2-hydroxyisonicotinate dehydrogenase are clearly distinct enzymes.

\section{Methods}

Organism, growth conditions, preparation of cell extracts, and solubilization of membrane-associated proteins. Mycobacterium sp. strain INA1 has been deposited at the Deutsche Sammlung von Mikroorganismen und Zellkulturen (DSM; Braunschweig, FRG) under the accession number DSM 6387. Conditions by its growth and the preparation of cell extracts have been described previously (Kretzer \& Andreesen, 1991). For large-scale cell growth fermenters with different volumes up to 3001 were used with stirring rates of 100 r.p.m. Speeds above 150 r.p.m. inhibited growth. Purification of isonicotinate dehydrogenase was started from extracts which were prepared in a buffer containing $50 \mathrm{~mm}$-sodium citrate and $50 \mathrm{~mm}-\mathrm{KCl}$ at $\mathrm{pH} 5.5$ (buffer A). Extracts were separated into soluble and membranous fractions by centrifugation at $100000 \mathrm{~g}$ for $2 \mathrm{~h}$. Membrane-associated isonicotinate dehydrogenase was solubilized by stirring the resuspended membranes ( $1 \mathrm{mg}$ protein per $\mathrm{ml}$ buffer $\mathrm{A}$ ) for $30 \mathrm{~min}$ at $0^{\circ} \mathrm{C}$ in the presence of $1 \%$ CHAPS. After a second ultracentrifugation, isonicotinate dehydrogenase activity was found in the supernatant.

Enzyme assays. All enzyme assays were performed at $30^{\circ} \mathrm{C}$. One unit $(\mathrm{U})$ is defined as the activity that converts $1 \mu \mathrm{mol}$ of substrate $\mathrm{min}^{-1}$. Isonicotinate dehydrogenase (Kretzer \& Andreesen, 1991), aconitase (Fansler \& Lowenstein, 1969) and isocitrate dehydrogenase (Cleland $e t$ al., 1969) were measured as described. Oxygen consumption in the presence of propane-1,2,3-tricarboxylate was measured using a Clark oxygen electrode (Rank). The reaction mixture contained $50 \mathrm{~mm}$ Tris/HCl ( $\mathrm{pH} \mathrm{8.0),} 1 \mathrm{~mm}$-propane-1,2,3-tricarboxylate, and various amounts of enzyme solution. Reduction of $\mathrm{NADP}^{+}$secondarily coupled to the oxidation of propane-1,2,3-tricarboxylate was measured by the increase of $A_{365}$ in $50 \mathrm{~mm}$-Tris/ $\mathrm{HCl}(\mathrm{pH} 7.0), 0.5 \mathrm{~mm}-\mathrm{MnCl}_{2}, 5 \mathrm{~mm}-$ propane-1,2,3-tricarboxylate and $0.5 \mathrm{~mm}-\mathrm{NADP}^{+}$. Aconitase and $\mathrm{NADP}^{+}$-dependent isocitrate dehydrogenase activities were responsible for the coupling between oxidation of propane-1,2,3-tricarboxylate and reduction of $\mathrm{NADP}^{+}$. These activities were either present in extracts of Mycobacterium sp. INA1 or were added to the reaction mixture [pig heart aconitase (about $20 \mathrm{U} \mathrm{g}^{-1}$ ) and isocitrate dehydrogenase (about $1 \mathrm{U} \mathrm{mg}^{-1}$ ), both from Sigma; added at $1.5 \mathrm{mg} \mathrm{m}^{-1}$.

\section{Separation and purification of proteins}

All the following steps were performed at $8^{\circ} \mathrm{C}$; chromatography media were obtained from Pharmacia.

Separation of the propane-1,2,3-tricarboxylate oxidizing system. This was achieved by gel filtration of soluble cell proteins on Sephacryl S-300 HR $(1.6 \times 95 \mathrm{~cm})$ as described by Kretzer \& Andreesen (1991).
Purification of isonicotinate dehydrogenase. This was performed using $50 \mathrm{~mm}$-sodium citrate with $50 \mathrm{mM}-\mathrm{KCl}, \mathrm{pH} 5 \cdot 5$ (buffer A) as principal buffer. Enrichment from either soluble cell proteins or solubilized membrane proteins followed the same procedure. CHAPS present in the membrane-derived protein fraction was almost completely removed during the first chromatographic step, and there was no need to supplement the subsequent elution buffers with a detergent. The starting protein solution was applied to Q-Sepharose fast flow equilibrated with buffer $A$ at a ratio of up to $50 \mathrm{mg}$ protein per $\mathrm{ml}$ of gel. The column was washed with 10 bed vols of 50 mM-citrate buffer containing $150 \mathrm{mM}-\mathrm{KCl}$ at $\mathrm{pH} 5 \cdot 5$. Bound protein was further eluted by a $150-600 \mathrm{~mm}-\mathrm{KCl}$ gradient that had about six times the volume of the anion exchange material. Isonicotinate dehydrogenase activity that eluted between 300 and $500 \mathrm{~mm}-\mathrm{KCl}$ was pooled and directly applied to Phenyl-Sepharose CL-4B equilibrated with $50 \mathrm{~mm}$-citrate buffer containing $300 \mathrm{~mm}-\mathrm{KCl}$ at $\mathrm{pH} 5 \cdot 5$. Protein was kept as low as $1 \mathrm{mg}$ per ml of gel material. The column was washed with $20 \%$ (v/v) ethylene glycol in buffer A. When the $A_{280}$ of the eluate had become constant, the ethylene glycol concentration was linearly raised from $20 \%$ to $60 \%$ (v/v), where it was kept, until isonicotinate dehydrogenase activity was completely eluted. The gradient had approximately 7.5 times the volume of the hydrophobic interaction material. Isonicotinate dehydrogenase eluted late in the gradient and was pooled and concentrated before gel permeation chromatography by binding to a small volume of well packed Q-Sepharose fast flow equilibrated with $40 \%$ ethylene glycol in buffer $\mathrm{A}$. After washing with buffer $\mathrm{A}$, the $\mathrm{KCl}$ concentration was raised stepwise from $50-500 \mathrm{~mm}$ so that the enzyme was eluted in a concentrated manner. Immediately afterwards it was subjected to gel filtration chromatography on either Sephacryl S-200 HR $(2.6 \times 90 \mathrm{~cm})$ or Superdex 200 prep grade $(1.6 \times 60 \mathrm{~cm})$, both run with buffer $A$ at $0.5 \mathrm{ml} \mathrm{min}^{-1}$. The former material was preferred for preparative purposes and the latter for molecular mass determinations.

Protein quantification. This was done by the method of Bradford (1976). Whenever stoichiometries were to be established, the method of Scopes (1974) was used in addition. Whereas quantifications of isonicotinate dehydrogenase by these two methods were in good agreement, the method of Elliot \& Brewer (1978) yielded lower values and was not used further. Standardization was done with bovine serum albumin.

\section{Characterization of isonicotinate dehydrogenase}

Inhibition by cyanide and methanol. This was tested according to Massey \& Edmondson (1970) and Coughlan et al. (1969).

Electrophoretic methods. For native gradient PAGE, the method of Blaschke et al. (1991) was principally followed, but a different electrode buffer was used (12.1 $\mathrm{g}$ Tris $\mathrm{1}^{-1}$ and $7.5 \mathrm{~g}$ glycine $\mathrm{I}^{-1}$, no $\mathrm{pH}$ adjustment). In the case of isonicotinate dehydrogenase, however, it was found that either running times had to be prolonged or polyacrylamide concentrations had to be raised, or both, to bring the enzyme into electrophoretic equilibrium, a prerequisite for molecular mass determinations on the basis of the molecular sieve effect described by Margolis \& Kenrick (1967). Appropriate conditions were electrophoresis across a gradient of $15-27.5 \%$ polyacrylamide for $24 \mathrm{~h}$ in the presence of suitable marker proteins. SDS-PAGE was performed by the system of Laemmli (1970) using $14 \%(\mathrm{w} / \mathrm{v})$ polyacrylamide gels, SDS gradient PAGE (5-20\% (w/v) polyacrylamide) was performed as described by Hames $(1981)(8.5 \times 7.0 \times 0.1 \mathrm{~cm}$ gels, run at $25 \mathrm{~mA})$. Visualization of protein bands was achieved by a silver stain (Blum et al., 1987).

Absorption spectra. UV/VIS-spectra of isonicotinate dehydrogenase were recorded with an Uvikon 810 spectrophotometer (Kontron).

Metal and cofactor determinations. Flavin. Flavin determinations were performed in the dark as far as possible. Flavin coenzyme was 
released from isonicotinate dehydrogenase by boiling for $10 \mathrm{~min}$, and the denatured protein was removed by centrifugation. Differentiation between FAD and FMN was achieved by thin layer chromatography on silica gel 60 plates (Merck) with the following solvent system: 1butanol:acetone: acetic acid: water $(5: 2: 1: 3$, by vol.). Spots of flavin were visible under UV light $(366 \mathrm{~nm})$ down to $0 \cdot 25 \mathrm{nmol}$. Salts derived from buffer $A$ in which isonicotinate dehydrogenase was usually prepared disturbed the chromatographic system. Therefore, isonicotinate dehydrogenase had to be desalted by repeated dilution with water and reconcentration in Centricon microconcentrators (Amicon) before qualitative determination of flavin. For the quantitative determination of FAD after its release from protein, an absorption coefficient of $\varepsilon_{450}=11.3 \mathrm{mM}^{-1} \mathrm{~cm}^{-1}$ was used (Koziol, 1971).

Molybdenum, iron and acid-labile sulphur. Molybdenum was determined by induced coupled plasma-MS, iron and acid-labile sulphur by the methods of Van de Bogart \& Beinert (1967) and of Beinert (1983), respectively.

Molybdenum cofactor. The presence of a molybdenum-complexing pterin was shown by derivatization to form $\mathrm{A}$ as described by Koenig \& Andreesen (1990). Molybdopterin cytosine dinucleotide was identified by two methods: (i) detection of CMP after acid hydrolysis of whole protein: isonicotinate dehydrogenase $(3 \mathrm{mg})$ was boiled for 20 min with $3 \%(\mathrm{w} / \mathrm{v}) \mathrm{H}_{2} \mathrm{SO}_{4}$, and the precipitated protein was removed by centrifugation. The supernatant was analysed by HPLC on an ET 250/8/4 Nucleosil 120-7 $\mathrm{C}_{18}$ column (Macherey \& Nagel) using a Waters 991 photodiode array detector. Elution was isocratic with 20 mm-potassium phosphate, $\mathrm{pH} 3.5$, at a flow rate of $0.5 \mathrm{ml} \mathrm{min}^{-1}$. (ii) Isolation of the carboxamidomethyl derivative, performing all the following steps at room temperature: isonicotinate dehydrogenase $(6 \mathrm{mg})$ was incubated overnight under anoxic conditions in the presence of a 3000 -fold molar excess of iodoacetamide, $6 \mathrm{M}$-guanidine $/ \mathrm{HCl}$ (stock solution at $\mathrm{pH} 7.2$ ), and 5 mm-sodium dithionite. The carboxamidomethyl derivative was subsequently handled without anoxic precautions. After 5-fold dilution with water, protein was precipitated by the addition of $40 \%(\mathrm{w} / \mathrm{v})$ ammonium sulphate and removed by centrifugation and filtration over glass wool. The clear solution was then applied to a reversed-phase $C_{18}$ cartridge $(0.8 \mathrm{ml}$ bed volume, Waters, Millipore) and after washing with $0.7 \mathrm{ml}$ water, retained substances were eluted with $5 \mathrm{ml}$ methanol. The methanolic solution was concentrated nearly to dryness by rotary evaporation. The residue was bright yellow due to the flavin content that, however, did not interfere with the further chromatographic analysis as it was strongly retained on the reversed phase $C_{18}$ material. The residue was made up to about $300 \mu \mathrm{l}$ with water and applied in aliquots to the HPLC system described above but using $50 \mathrm{~mm}$-ammonium acetate, $\mathrm{pH} 6.8$, as the eluent $\left(1 \mathrm{ml} \mathrm{min}^{-1}\right)$. Carboxamidomethylmolybdopterin cytosine dinucleotide from carbon monoxide dehydrogenase of Hydrogenophaga pseudoflava (formerly Pseudomonas carboxydoflava) was prepared under the same conditions.

$N$-Terminal amino acid sequences. $\mathrm{N}$-Terminal amino acids sequences of protein subunits were determined as described by Hughes et al. (1992).

\section{Results} Detection of propane-1,2,3-tricarboxylate-oxidizing
activity

Extracts of Mycobacterium sp. INA1 catalysed a propane-1,2,3-tricarboxylate-dependent oxygen consumption with an activity of about $40 \mathrm{U}$ (g protein) ${ }^{-1}$. In addition, a reduction of $\mathrm{NADP}^{+}$was also measured in the presence of propane-1,2,3-tricarboxylate and soluble proteins derived from Mycobacterium sp. INA1. In contrast to the oxygen consumption, the NADP' reduction was not linear from the start but became linear after a few minutes, a fact indicating a multi-component system. These components were resolved by gel filtration chromatography (Fig. 1). Two protein fractions, termed I and II in the order of their elution, restored the $\mathrm{NADP}^{+}$-reducing activity in the presence of propane1,2,3-tricarboxylate. Fraction I contained aconitase and $\mathrm{NADP}^{+}$-dependent isocitrate dehydrogenase activities, and fraction II the propane-1,2,3-tricarboxylate oxidizing enzyme. Fraction I could be replaced by aconitase and isocitrate dehydrogenase activities from pig heart to restore $\mathrm{NADP}^{+}$-reducing activity in the presence of fraction II and propane-1,2,3-tricarboxylate. It was concluded that fraction II converted propane-1,2,3tricarboxylate to aconitate and that further metabolism of the latter occurred in the presence of fraction I and led to a NADP $^{+}$-reduction via aconitase and isocitrate dehydrogenase. Oxidation of propane-1,2,3-tricarboxylate to aconitate occurred in vitro with oxygen as electron acceptor as deduced from the oxygen consumption results and from the fact that $\mathrm{NADP}^{+}$-reduction was

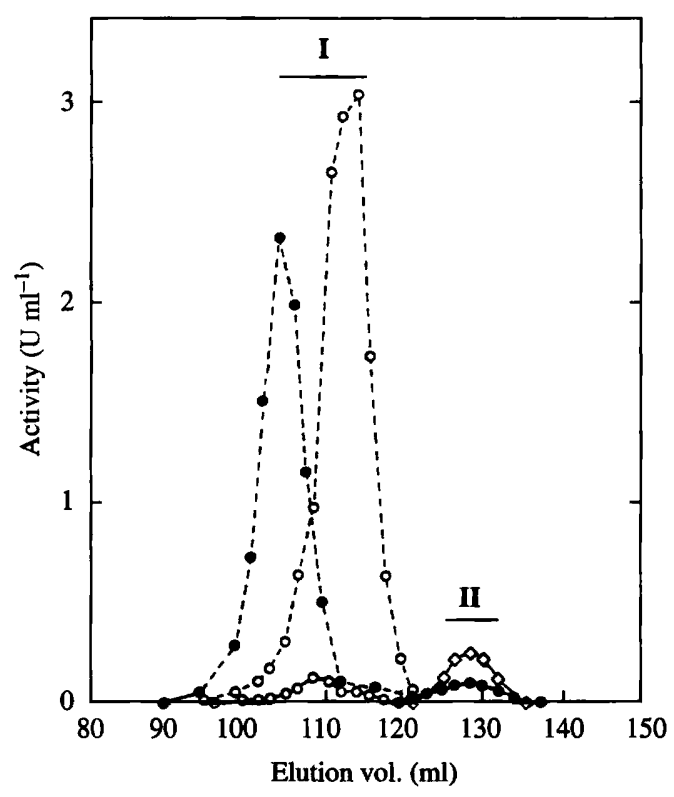

Fig. 1. Elution profiles of enzyme activities involved in the oxidation of propane-1,2,3-tricarboxylate, when separated on Sephacryl S-300 HR. Bars indicate the protein pools that were termed fractions I and II. -- --, Isocitrate dehydrogenase activity; --O-- aconitase activity; $O$, activity (activities) that complemented fraction II to restore $\mathrm{NADP}^{+}$reduction by propane-1,2,3-tricarboxylate; $\boldsymbol{O}$, activity that complemented fraction $\mathrm{I}$ to restore $\mathrm{NADP}^{+}$reduction by propane1,2,3-tricarboxylate; $\diamond$, activity that was complemented with aconitase and isocitrate dehydrogenase from pig heart to restore $\mathrm{NADP}^{+}$ reduction by propane-1,2,3-tricarboxylate. The elution volumes corresponded approximately to molecular masses of $250 \mathrm{kDa}$ (isocitrate dehydrogenase), $120 \mathrm{kDa}$ (aconitase) and $40 \mathrm{kDa}$ (fraction II). 
Table 1. Purification protocol for isonicotinate dehydrogenase from soluble cell protein of Mycobacterium sp. INA1

\begin{tabular}{lccccccc}
\hline \hline & \multicolumn{2}{c}{ Protein } & & \multicolumn{3}{c}{ Activity } \\
\cline { 2 - 3 } \cline { 5 - 7 } Purification step & $\begin{array}{l}\text { Total } \\
\text { (mg) }\end{array}$ & $\% \dagger$ & & $\begin{array}{c}\text { Total } \\
(\mathrm{U})\end{array}$ & $\% \dagger$ & $\left(\mathrm{U} \mathrm{mg} \mathrm{m}^{-1}\right)$ & $\begin{array}{c}\text { Purification } \\
\text { factor }\end{array}$ \\
\hline Soluble cell protein & 308 & 100 & & 167 & 100 & 0.54 & - \\
Q-Sepharose & 11.5 & 4 & & 95 & 57 & 8.2 & 15 \\
Phenyl-Sepharose & 1.6 & 0.5 & & 25 & 15 & 15.7 & 29 \\
Superdex 200* & 0.47 & 0.15 & & 3.5 & 2 & 7.5 & 14 \\
\hline \hline
\end{tabular}

* Only peak fractions were pooled.

$\dagger$ Activity and protein content of the soluble cell protein fraction was taken as $100 \%$.

oxygen-dependent and did not occur under anaerobic conditions. Therefore, an oxygen-dependent propane1,2,3-tricarboxylate oxidase is responsible for this transformation. The reaction product, aconitate, is in the usual cis-conformation, as Mycobacterium sp. INAl only possessed cis-aconitase activity.

\section{Purification and characterization of isonicotinate dehydrogenase}

Isonicotinate dehydrogenase from Mycobacterium sp. INA1 was found to be partly membrane-associated. The degree of membrane association increased from $20-30 \%$ to about $70 \%$ in the late-exponential growth phase, due to a rapid decrease of specific activity from about 360 to $80 \mathrm{U}$ ( $\mathrm{g}$ protein $)^{-1}$ in the soluble fraction when isonicotinate disappeared from the medium. Specific activity, on the other hand, remained quite stable in the membrane fraction (approximately $1000 \mathrm{U} \mathrm{g}^{-1}$ ). No differences could be observed between the enzymes purified from these two fractions, either in chromatographic behaviour or in catalytic and structural properties.

Purification of isonicotinate dehydrogenase to apparent homogeneity was achieved using anion exchange chromatography, hydrophobic interaction chromatography, and gel permeation chromatography as described in Methods, and a representative purification protocol is given in Table 1. For unknown reasons, isonicotinate dehydrogenase activity was somewhat unstable, and a decrease in specific activity occurred during the late steps of purification, either during hydrophobic interaction chromatography or during gel permeation chromatography. Several modifications have been considered to account for the inactivation of related enzymes, as has been thoroughly discussed for a nicotinate dehydrogenase (Nagel \& Andreesen, 1990).

Purified isonicotinate dehydrogenase from Mycobacterium sp. INA1 had a pH optimum at 9.5 and a $K_{\mathrm{m}}$ (for isonicotinate) of $1 \mathrm{~mm}$ in pyrophosphate buffer at that $\mathrm{pH}$. The enzyme proved to be rather substrate-specific.
Table 2. Catalytic properties of isonicotinate dehydrogenase from Mycobacterium sp. INAI

\begin{tabular}{ll}
\hline \multicolumn{1}{c}{ Property } \\
\hline pH optimum* & 9.5 \\
$K_{\mathrm{m}}$ at pH 8.2 $\left(\mathrm{mm}^{-1}\right) \dagger$ & 0.21 \\
$K_{\mathrm{m}}$ at $\mathrm{pH} 9.5\left(\mathrm{~mm}^{-1}\right) \dagger$ & 1.03 \\
Optimal assay temperature $\left({ }^{\circ} \mathrm{C}\right)$ & 60 \\
Substrate spectrum (activity in $\%) \ddagger$ & 100 \\
Isonicotinate & 17 \\
Quinoline-4-carboxylate & 2.6 \\
Pyridine-3,4-dicarboxylate & 1.6 \\
Pyridine-2,3-dicarboxylate & 1.4 \\
$N$-Methylisonicotinate & \\
\hline
\end{tabular}

*The optimal $\mathrm{pH}$ was determined using the following buffers $(40 \mathrm{~mm}$ each): Tris/ $\mathrm{HCl}, \mathrm{pH} 8.5,9.0,9.5$; sodium pyrophosphate $/ \mathrm{KOH}$, pH 9.5, 10.0; glycine/ $\mathrm{NaOH}, \mathrm{pH} 9 \cdot 0,9 \cdot 5,10 \cdot 0,10 \cdot 5$.

$\dagger$ Recorded in Tris $/ \mathrm{HCl}, \mathrm{pH} 8 \cdot 2$, and pyrophosphate buffer, $\mathrm{pH} 9 \cdot 5$, respectively.

$\ddagger$ The tested substrates were all $5 \mathrm{~mm}$; activity with isonicotinate was set to be $100 \%$; zero activity was found with 2-hydroxyisonicotinate, isoniazid, 4-chloropyridine, nicotinate, picolinate, xanthine and hypoxanthine.

Besides isonicotinate, only quinoline-4-carboxylate (= 'benzoisonicotinate') was found to be oxidized at appreciable rates (Table 2). No activity could be measured with 2-hydroxyisonicotinate. The 2-hydroxyisonicotinate-oxidizing activity present in cell extracts was separated from isonicotinate dehydrogenase during the first enrichment step. Whereas isonicotinate dehydrogenase bound to the anion exchange material under the application conditions described, 2-hydroxyisonicotinate dehydrogenase did not. This is in contrast to isonicotinate- and 2-hydroxyisonicotinate-oxidizing activities of Micrococcus sp. (Gupta \& Shukla, 1979b) which co-purified. A single enzyme was supposed to be responsible for both reactions, but final proof for this was lacking, since pure preparations were not obtained, nor was the enzyme structurally characterized.

Isonicotinate dehydrogenase of Mycobacterium sp. 
(a)

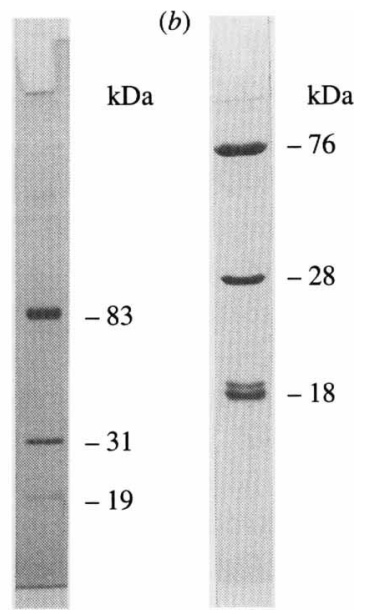

Fig. 2. Subunits of isonicotinate dehydrogenase as revealed by SDSPAGE. (a) SDS gradient PAGE; (b) homogeneous SDS-PAGE.

INA1 was estimated to have a molecular mass of either $125 \pm 3 \mathrm{kDa}$ (by native gradient PAGE) or $250 \pm 10 \mathrm{kDa}$ (by gel filtration chromatography). SDS-PAGE revealed three different types of subunits (see below), and it was assumed that the purified enzyme existed in vitro either as a $(\alpha \beta \gamma)$ monomer or as a $(\alpha \beta \gamma)_{2}$ dimer depending on the experimental conditions. Under the conditions described, both forms exhibited enzymic activity. The native state in vivo is not known. Subunit sizes were determined either by SDS gradient PAGE to be about 83,31 and $19 \mathrm{kDa}$ or by homogeneous SDS-PAGE to be 76, 28 and $18 \mathrm{kDa}$. Because of the acrylamide gradient, the 18 $19 \mathrm{kDa}$ subunit stained weakly in SDS gradient gels. In continuous, non-gradient SDS gels, it ran, for unknown reasons, either in a diffuse manner or as a double band (Fig. 2). The presence of an impurity or a fourth subunit were not considered as possible reasons for this curious running behaviour, as $\mathrm{N}$-terminal amino acid sequencing did not yield a double sequence. Partial degradation, however, cannot be excluded. N-Terminal amino acid sequences of all three subunits of isonicotinate dehydrogenase are shown in Fig. 3.

Earlier studies had shown that expression of active isonicotinate dehydrogenase required molybdenum

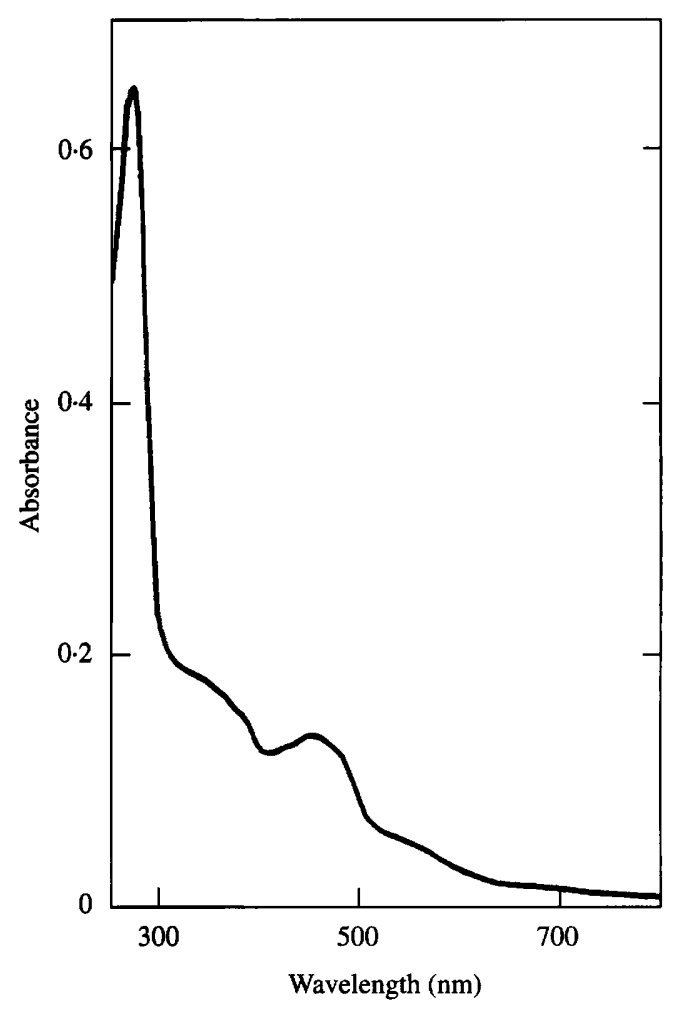

Fig. 4. Absorption spectrum of isonicotinate dehydrogenase from Mycobacterium sp. INA1.

(Kretzer \& Andreesen, 1991). In addition, $10 \mathrm{~mm}$-cyanide and $1.5 \mathrm{M}$-methanol, both known inhibitors of molybdoenzymes (Coughlan et al., 1969) were found to inhibit isonicotinate dehydrogenase activity almost completely in the soluble cell protein fraction. Purified isonicotinate dehydrogenase was found to be somewhat less sensitive to inhibition.

The presence of further redox-active components besides molybdenum was indicated by the absorption spectrum of purified isonicotinate dehydrogenase. A maximum around $450 \mathrm{~nm}$ and a shoulder around $550 \mathrm{~nm}$ pointed to the presence of flavin and iron-sulphur clusters (Fig. 4). The non-covalently-bound flavin was identified as FAD. Molybdenum, iron, acid-labile sulphur, and FAD were determined to be present at ratios 


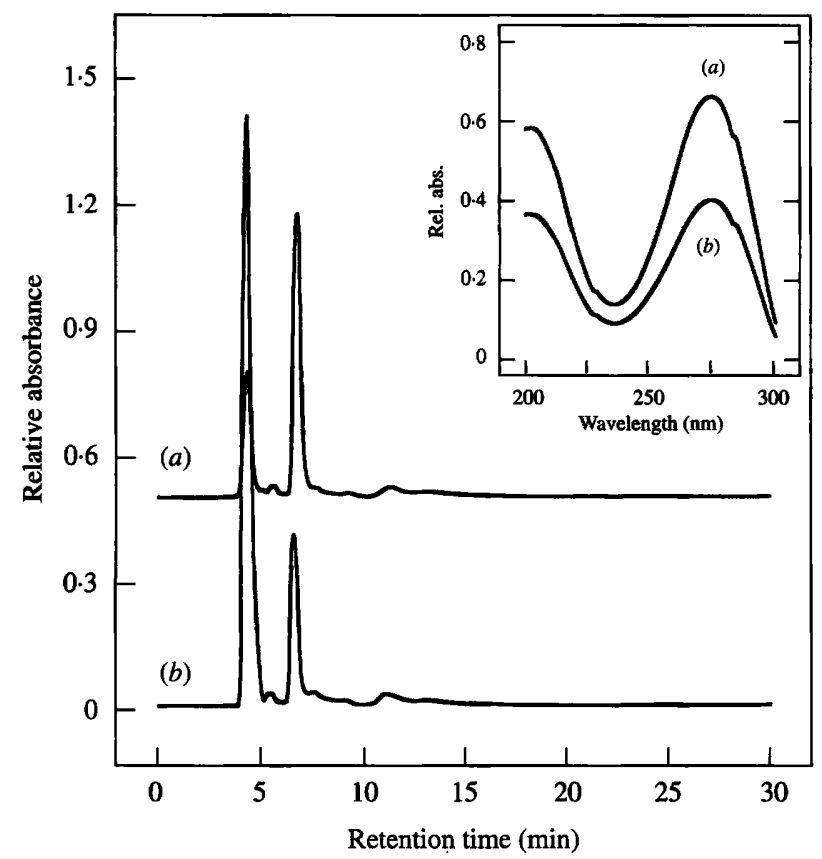

Fig. 5. Identification of 5'-CMP. HPLC elution profiles of the supernatant of acid-treated isonicotinate dehydrogenase $(a)$ and of the same amount of supernatant after addition of authentic 5'-CMP (b) recorded at $270 \mathrm{~nm}$. The inset shows the absorption spectra of peaks eluting at $7 \mathrm{~min}$ without $(a)$ and with addition of authentic $5^{\prime}$-CMP $(b)$.

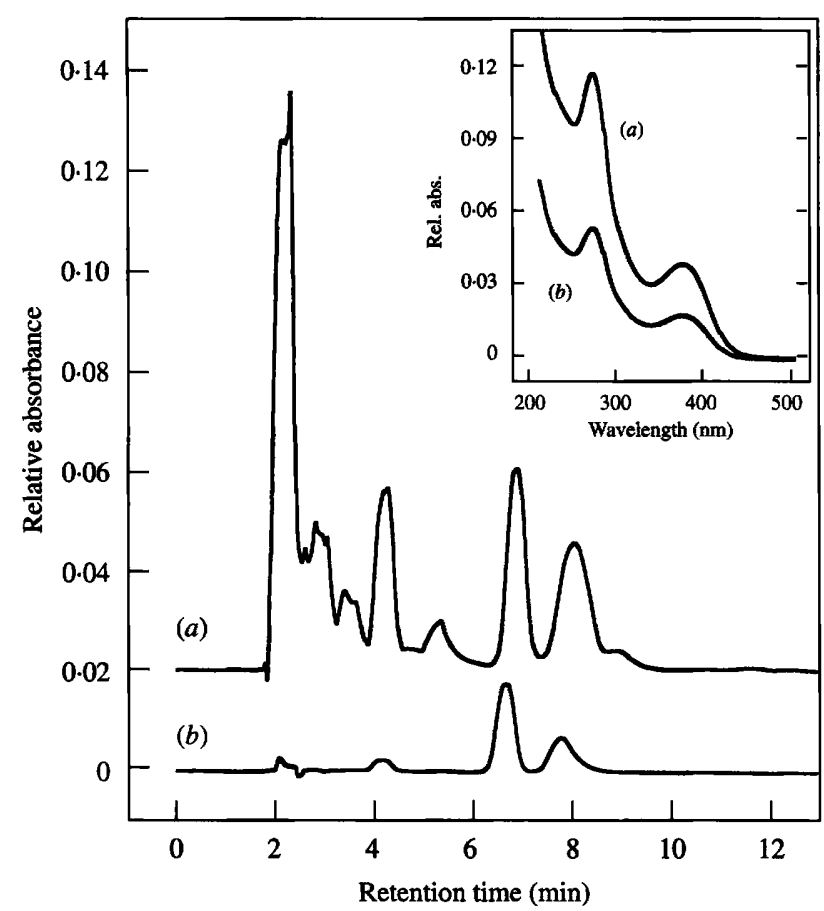

Fig. 6. Identification of MCD in isonicotinate dehydrogenase. Elution profiles of the carboxamidomethylmolybdopterin derivative obtained from isonicotinate dehydrogenase $(a)$ and purified camMCD from Hydrogenophaga pseudoflava carbon monoxide dehydrogenase $(b)$ were recorded at $370 \mathrm{~nm}$. Absorption spectra of the same substances eluting between 6.5 and $6.8 \mathrm{~min}$ are given in the inset. of $0.93,4.12,4.09,0.95 \mathrm{mols}$ per mol of the native $125 \mathrm{kDa}$ protein. The presence of a molybdenumcomplexing pterin cofactor was shown by the characteristic fluorescence of the form A derivative (data not shown) (Johnson \& Rajagopalan, 1982). For the following reasons it was concluded that molybdopterin cytosine dinucleotide was the organic moiety of the molybdenum cofactor: (i) when isonicotinate dehydrogenase was subjected to acid hydrolysis, a compound was detected in the supernatant by reversed-phase HPLC that exactly coeluted with authentic 5'-CMP and exhibited essentially the same absorption spectrum (Fig. 5); (ii) when the carboxamidomethyl derivative of the molybdenum cofactor was prepared and isolated, it eluted from Nucleosil 120-7 RP18 exactly like carboxamidomethylmolybdopterin cytosine dinucleotide (camMCD) from carbon monoxide dehydrogenase of Hydrogenophaga pseudoflava. The camMCDs from both isonicotinate dehydrogenase and carbon monoxide dehydrogenase eluted as double peaks due to the monoand dicarboxamidomethylated forms. The presence of different molybdopterin dinucleotides in isonicotinate dehydrogenase, as described for formylmethanofuran dehydrogenase from Methanobacterium thermoautotrophicum (Börner et al., 1991), was not considered, since the same double peak was obtained with camMCD from carbon monoxide dehydrogenase of Hydrogenophaga pseudoflava, an enzyme known to contain only molybdopterin cytosine dinucleotide (Johnson et al., 1990), and both pterin peaks exhibited essentially the same absorption spectra that were identical to those obtained from carbon monoxide dehydrogenase camMCD (Fig. 6).

\section{Discussion}

Degradation of isonicotinate by Mycobacterium $s p$. INAI

In an earlier paper we described the isolation of a mycobacterial species that metabolizes isonicotinate as the sole source of carbon, nitrogen, and energy (Kretzer \& Andreesen, 1991). Bacterial growth on isonicotinate had been described before for a Pseudomonas sp. (Ensign \& Rittenberg, 1965), a Micrococcus sp. (formerly called Sarcina sp.) (Gupta \& Shukla, 1979a), and a Bacillus brevis strain (Singh \& Shukla, 1986). For the latter two organisms, degradation pathways have been proposed that differ from that found in Mycobacterium sp. INA1.

Mycobacterium sp. INA1 shares the first two hydroxylation reactions that yield citrazinate (2,6-dihydroxyisonicotinate) with Pseudomonas sp. and Micrococcus sp. (Kretzer \& Andreesen, 1991). However, further metabolism of citrazinate was found to follow 


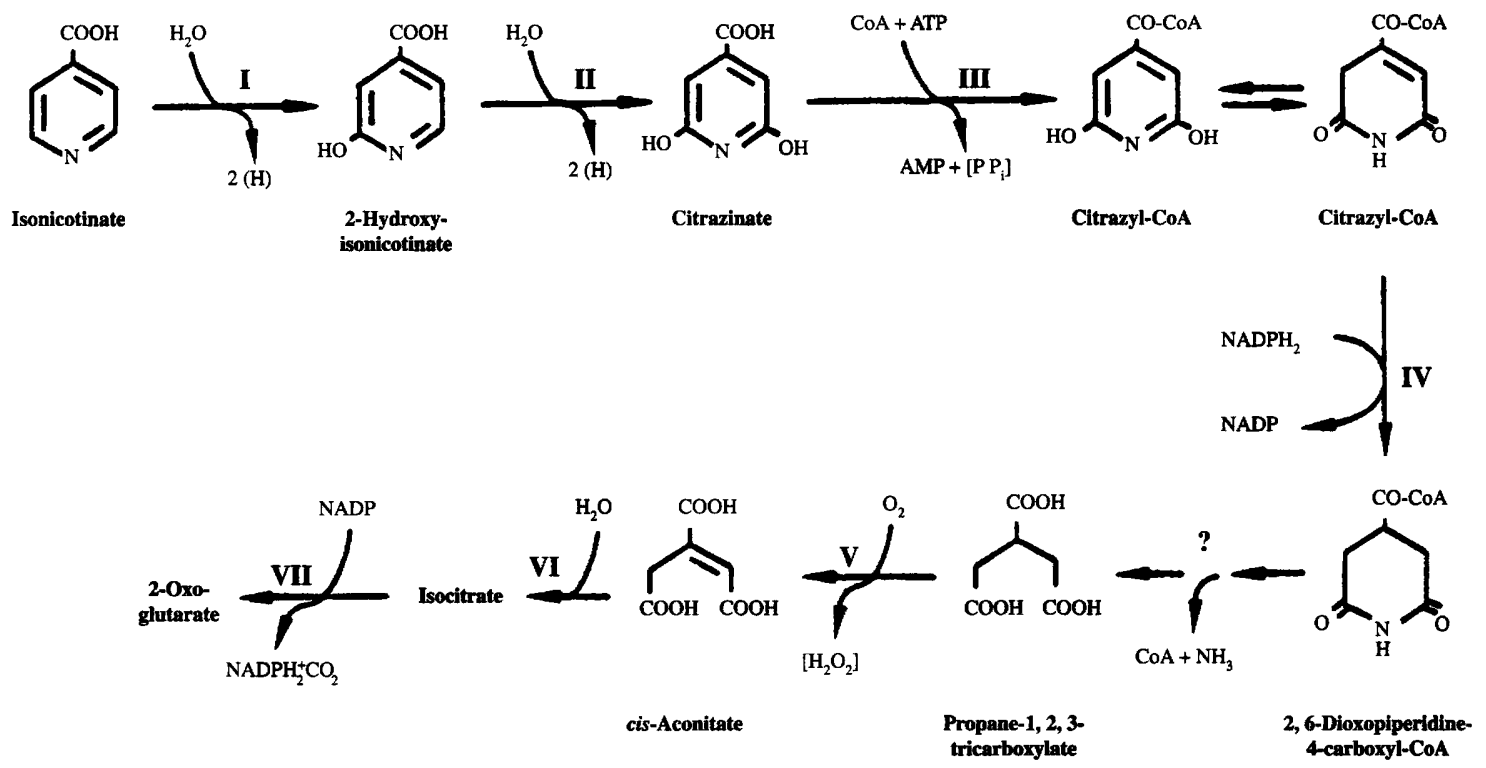

Fig. 7. Proposed pathway of isonicotinate metabolism in Mycobacterium sp. INA1. Enzymes: (I) isonicotinate dehydrogenase; (II) 2hydroxyisonicotinate dehydrogenase; (III) citrazyl-CoA synthetase; (IV) citrazyl-CoA reductase; (V) propane-1,2,3-tricarboxylate oxidase; (VI) cis-aconitase; (VII) isocitrate dehydrogenase.

a previously unknown route involving CoA-ester intermediates. In the case of Pseudomonas sp., no metabolic steps beyond citrazinate have been resolved at all, but as resting cells of Pseudomonas sp. quickly oxidized citrazinate, the latter was thought to be a real intermediate (Ensign \& Rittenberg, 1965). In the case of Micrococcus sp., direct hydrolytic cleavage of citrazinate to yield cisaconitamide was at first postulated (Gupta \& Shukla, $1979 a$ ). Failure to measure this reaction, as well as the fact that Micrococcus sp. did not metabolize citrazinate, prompted the authors to consider citrazinate as a metabolic dead-end (Sharma \& Shukla, 1987). However, following our observations on isonicotinate metabolism by Mycobacterium sp. INA1, these facts do not necessarily contradict an involvement of citrazinate as a true intermediate (Kretzer \& Andreesen, 1991).

2-Hydroxyisonicotinate and citrazinate were finally also shown to be intermediates in $N$-methylisonicotinate metabolism by the unidentified Gram-positive strain 4C1 (Orpin et al., 1972). A further intermediate was maleamate. Although the links were missing, it seemed very reasonable in that case to postulate an oxygenase reaction that cleaved the aromatic ring between $\mathrm{C}_{2}$ and $\mathrm{C}_{3}$ in either citrazinate or 2,6-dihydroxypyridine. A variety of pyridine compounds are metabolized via similar reaction sequences - often referred to as the 'maleamate pathway' - that generally do not involve CoA-ester intermediates (Shukla, 1984).

Our previous work had demonstrated that isonicotinate metabolism in Mycobacterium sp. INA1 did not follow one of these known routes but involved activation of citrazinate to its CoA-ester and $\mathrm{NADPH}+\mathrm{H}^{+}-$ dependent reduction of the latter. A physiological demand for this energy-dependent activation of citrazinate is not discernible, but it is proposed that the ester function activates citrazinate for a nucleophilic attack of a hydride ion in the course of the reduction. An analogous catalytic role was proposed for the involvement of CoA-ester intermediates in the bacterial dehalogenation of 4-chlorobenzoate that might succeed via a nucleophilic substitution (Copley \& Crooks, 1992; Löffler et al., 1992).

The reduction of citrazyl-CoA yields 2,6-dioxopiperidine-4-carboxyl-CoA and further metabolism has been shown to yield 2-oxoglutarate (Kretzer \& Andreesen, 1991). The detection of a cis-aconitate-generating propane-1,2,3-oxidizing system as presented in this paper has narrowed the gap of knowledge in isonicotinate metabolism by Mycobacterium sp. INA1 (Fig. 7). Only two more reactions remain to be established: CoA-ester hydrolysis or a CoA transferase reaction, and hydrolysis of the cyclic imide function.

\section{Isonicotinate dehydrogenase from Mycobacterium sp. INAI}

Hydroxylations in the neighbourhood of the nitrogen like those converting isonicotinate to citrazinate - are very common in the bacterial metabolism of pyridine derivatives. Some of the responsible dehydrogenases from very different bacteria have been purified and all of them were found to be molybdenum-containing hy- 
Table 3. Comparison of selected molybdenum-containing hydroxylases

Abbreviations: DH, dehydrogenase; MoCo, molybdenum cofactor; MPT, molybdopterin; MCD, molybdopterin cytosine; MGD, molybdopterin guanine dinucleotide; ND, not determined.

\begin{tabular}{|c|c|c|c|c|c|c|c|c|c|c|c|c|c|}
\hline \multirow[b]{2}{*}{ Enzyme } & \multirow[b]{2}{*}{ Organism } & \multirow{2}{*}{$\begin{array}{l}\text { Mol. } \\
\text { mass } \\
(\mathrm{kDa})\end{array}$} & \multirow{2}{*}{\multicolumn{3}{|c|}{$\begin{array}{l}\text { Subunits } \\
\text { (kDa) }\end{array}$}} & \multicolumn{4}{|c|}{ Redox-active centres* } & \multicolumn{3}{|c|}{$\begin{array}{l}\text { Specification of } \\
\text { centres }\end{array}$} & \multirow[b]{2}{*}{ Reference } \\
\hline & & & & & & Mo & $\mathrm{Fe}$ & $\mathbf{S}$ & Flavin & MoCo & $\mathrm{FeS}$ & Flavin & \\
\hline \multicolumn{14}{|c|}{ Molybdenum-containing hydroxylases that exhibit strong structural similarities } \\
\hline Nicotinate DH & Bacillus niacini & 300 & 85 & 34 & 20 & 0.8 & $4 \cdot 2$ & $0 \cdot 8$ & 1.0 & $\mathrm{MCD} \dagger$ & ND & FAD & $\begin{array}{l}\text { Nagel \& } \\
\text { Andreesen } \\
(1990)\end{array}$ \\
\hline 6-Hydroxynicotinate DH & Bacillus niacini & 120 & 85 & 34 & 15 & ND & ND & ND & ND & MGD $\dagger$ & ND & FAD & $\begin{array}{l}\text { Nagel \& } \\
\text { Andreesen } \\
(1990)\end{array}$ \\
\hline Nicotine DH & Arthrobacter ureafaciens $\ddagger$ & 120 & 82 & 30 & 15 & 0.9 & $4 \cdot 0$ & $2 \cdot 0$ & 0.9 & ND & ND & FAD & $\begin{array}{l}\text { Freudenberg et } \\
\text { al. (1988) }\end{array}$ \\
\hline Quinoline DH & Pseudomonas putida 86 & 300 & 85 & 30 & 19 & 0.8 & $3 \cdot 4$ & $4 \cdot 3$ & 0.8 & MCD & ND & FAD & $\begin{array}{l}\text { Hettrich et al. } \\
\text { (1991) }\end{array}$ \\
\hline Quinoline DH & Rhodococcus sp. B1 & 300 & 82 & 32 & 18 & 0.6 & $3 \cdot 7$ & $3 \cdot 7$ & 0.9 & MCD & ND & FAD & $\begin{array}{l}\text { Peschke \& } \\
\text { Lingens (1991) }\end{array}$ \\
\hline $\begin{array}{l}\text { Quinoline-4-carboxylate } \\
\text { DH }\end{array}$ & Agrobacterium sp. 1B & 320 & 85 & 35 & 21 & $1 \cdot 1$ & $4 \cdot 2$ & $3 \cdot 6$ & 0.9 & MCD & ND & FAD & $\begin{array}{l}\text { Bauer \& Lingens } \\
\text { (1992) }\end{array}$ \\
\hline Isonicotinate $\mathrm{DH}$ & Mycobacterium sp. INA1 & 125 & 83 & 31 & 19 & 0.9 & $4 \cdot 1$ & $4 \cdot 1$ & 1.0 & MCD & ND & FAD & This work \\
\hline Quinaldine DH & Arthrobacter sp. Rü 61a & 340 & 82 & 35 & 22 & 0.8 & $4 \cdot 0$ & $3 \cdot 8$ & 0.9 & MCD & ND & FAD & $\begin{array}{l}\text { De Beyer \& } \\
\text { Lingens (1993) }\end{array}$ \\
\hline Carbon monoxide $\mathrm{DH}$ & $\begin{array}{l}\text { Carboxydotrophic } \\
\text { bacteria }\end{array}$ & $\sim 260$ & $\sim 80$ & $\sim 30$ & $\sim 15$ & $1 \cdot 0$ & $4 \cdot 0$ & $4 \cdot 0$ & $1 \cdot 0$ & MCD & $\mathrm{Fe}_{2} \mathrm{~S}_{2}$ & FAD & $\begin{array}{l}\text { Johnson et al. } \\
(1990)\end{array}$ \\
\hline Xanthine DH§ & Clostridium barkeri & 535 & 81 & 30 & 18 & $0 \cdot 6$ & $2 \cdot 1$ & ND & ND & ND & $\mathrm{Fe}_{2} \mathrm{~S}_{2}$ & FAD & Rienhöfer (1985) \\
\hline Xanthine DH & Pseudomonas putida 86 & 550 & 87 & 52 & & 1.0 & $3 \cdot 6$ & $4 \cdot 0$ & $1 \cdot 0$ & MPT & ND & FAD & $\begin{array}{l}\text { Hettrich et al. } \\
\text { (1991) }\end{array}$ \\
\hline Nićotinate $\mathrm{DH} \|$ & Aspergillus nidulans & 300 & 153 & & & $1 \cdot 0$ & $4 \cdot 3$ & ND & $1 \cdot 0$ & ND & $\mathrm{Fe}_{2} \mathrm{~S}_{2}$ & FAD & $\begin{array}{l}\text { Coughlan et al. } \\
\text { (1984) }\end{array}$ \\
\hline Xanthine DH/oxidase & Mammals and birds & $\sim 300$ & $\begin{array}{r}\sim 150 \\
\sim 85\end{array}$ & $\sim 40$ & & $\begin{array}{l}1.0 \\
\text { (dom: }\end{array}$ & ains) & $4 \cdot 0$ & $1 \cdot 0$ & MPT & $\mathrm{Fe}_{2} \mathrm{~S}_{2}$ & FAD & $\begin{array}{l}\text { Amaya et al. } \\
(1990)\end{array}$ \\
\hline \multicolumn{14}{|c|}{ Molybdenum-containing hydroxylases that differ in their structure and composition from the above listed enzymes } \\
\hline Xanthine'DH & Pseudomonas putida Ful & 300 & 55 & 25 & & $0 \cdot 4$ & $1 \cdot 5$ & 0.6 & $-\pi$ & MGD§ & ND & - & $\begin{array}{l}\text { Koenig \& } \\
\text { Andreesen } \\
\text { (1990) }\end{array}$ \\
\hline Furoyl-CoA DH & Pseudomonas putida Ful & 150 & 55 & 25 & & ND & ND & ND & $-\Phi$ & MAD§ & ND & - & $\begin{array}{l}\text { Koenig \& } \\
\text { Andreesen } \\
\text { (1990) }\end{array}$ \\
\hline
\end{tabular}

* Values refer to molar ratios per protomer, sulphur being determined as acid-labile sulphur.

$\dagger \mathrm{K}$. Frunzke, personal communication.

$\ddagger$ Formerly known as strain of Arthrobacter oxydans.

$\S$ Enzyme contains additionally $0.3 \mathrm{~W}$ and 0.2 Se.

$\|$ Also described as 'purine hydroxylase II'.

II Instead of FAD, cytochrome $b$ is present; for xanthine dehydrogenase, the ratio was determined to be $0 \cdot 2$ cytochrome $b$ per protomer in the final preparation.

droxylases with striking similarities (Table 3). Isonicotinate dehydrogenase from Mycobacterium sp. INA1 (this work) fits into that group whose general features are: $(\alpha \beta \gamma)$ or $(\alpha \beta \gamma)_{2}$ structure with subunit sizes of about 85 , 30 and $20 \mathrm{kDa}$ and presence of 1 atom of molybdenum, 4 atoms of iron, 4 atoms of acid-labile sulphur and $1 \mathrm{~mol}$ FAD per protomer. In nearly all cases, MCD was shown to be the molybdenum-complexing cofactor of those enzymes specifically acting on pyridine derivatives. Only 6-hydroxynicotinate DH from Bacillus niacini, an organism that contains two similar molybdoenzymes, both involved in the catabolism of nicotinate, was found to contain MGD.

Some other molybdenum-containing hydroxylases share most of the structural properties with the above mentioned enzymes, e.g. carbon monoxide dehydrogenases from carboxydotrophic bacteria and some bacterial xanthine dehydrogenases (Table 3). Corresponding eukaryotic molybdoenzymes also exhibit great similarities in their content of redox-active components though having a dissimilar $\alpha_{2}$ homodimeric structure (Coughlan, 1980). That is also true for a rather substrate- 
unspecific enzyme called 'purine hydroxylase II' from Aspergillus nidulans. This enzyme is actually a eukaryotic nicotinate dehydrogenase (Lewis et al., 1978; Coughlan et al., 1984). The best characterized eukaryotic hydroxylases are the xanthine oxidases/dehydrogenases from mammalian and avian sources. In these cases the homodimers were shown by partial proteolytic cleavage to be composed of $\left(\alpha_{1} \alpha_{\mathrm{II}} \alpha_{\mathrm{III}}\right)_{2}$ domains connected by hinge peptides (Coughlan, 1980). In the case of xanthine dehydrogenase from rat liver, results indicate that the molybdenum cofactor, the $\mathrm{Fe}_{2} \mathrm{~S}_{2}$ clusters, and the FAD are located on the 85,20 and $40 \mathrm{kDa}$ domains, respectively (Amaya et al., 1990). Domain structure and location of the redox-active centres has been confirmed by DNA homology studies (Wootton et al., 1991). The eukaryotic domains might be functional analogues of the bacterial subunits.

The authors are very grateful to Dr D. Hochstrasser (Centre Medical Universitaire, Genève, Switzerland) for the determination of $\mathrm{N}$ terminal amino acid sequences, to R. Cicciarelli (Lonza AG, Visp, Switzerland) for molybdenum determinations, and to Dr R. Brinkmann (Institut für Mikrobiologie der Universität Göttingen) for large scale fermentations.

\section{References}

Aislabie, J., Rothenburger, S. \& Atlas, R. M. (1989). Isolation of microorganisms capable of degrading isoquinoline under aerobic conditions. Applied and Environmental Microbiology 55, 3247-3249.

Amaya, Y., Yamazaki, K., Sato, M., Noda, K., Nishino, T. \& Nishino, T. (1990). Proteolytic conversion of xanthine dehydrogenase from the NAD-dependent type to the $\mathrm{O}_{2}$-dependent type. Amino acid sequence of rat liver xanthine dehydrogenase and identification of the cleavage sites of the enzyme protein during irreversible conversion by trypsin. Journal of Biological Chemistry $265,14170-14175$.

BAUER, G. \& LINGENS, F. (1992). Microbial metabolism of quinoline and related compounds. XV. Quinoline-4-carboxylic acid oxidoreductase from Agrobacterium spec. 1B: a molybdenum-containing enzyme. Biological Chemistry Hoppe-Seyler 373, 699-705.

BEINERT, H. (1983). Semi-micro methods for analysis of labile sulfide and of labile sulfide plus sulfane sulfur in unusually stable iron-sulfur proteins. Analytical Biochemistry 131, 373-378.

BlaschKe, M., Kretzer, A., SchäFer, C., NAGel, M. \& ANdreesen, J. R. (1991). Molybdenum-dependent degradation of quinoline by Pseudomonas putida Chin IK and other aerobic bacteria. Archives of Microbiology 155, 164-169.

BLOCK, D. W. \& LINGENS, F. (1992). Microbial metabolism of quinoline and related compounds. XIII. Purification and properties of $1 \mathrm{H}-4-$ oxoquinoline monooxygenase from Pseudomonas putida strain 33/1. Biological Chemistry Hoppe-Seyler 373, 249-254.

BLUM, H., BEIER, H. \& GROSs, H. J. (1987). Improved silver staining of plant proteins, RNA, and DNA in polyacrylamide gels. Electrophoresis 8, 93-99.

BöRNER, G., KARRASCh, M. \& ThaUer, R. K. (1991). Molybdopterin adenine dinucleotide and molybdopterin hypoxanthine dinucleotide in formylmethanofuran dehydrogenase from Methanobacterium thermoautotrophicum (Marburg). FEBS Letters 290, 31-34.

BRADFORD, M. M. (1976). A rapid and sensitive method for quantitation of microgram quantities of protein utilizing the principle of protein-dye binding. Analytical Biochemistry 72, 248-254.

BRAY, R. C. (1988). The inorganic biochemistry of molybdoenzymes. Quarterly Reviews of Biophysics 21, 299-329.

BuDDIN, W. (1914). Partial sterilisation of soil by volatile and nonvolatile antiseptics. Journal of Agricultural Science 6, 417-451.
Cleland, W. W., Thompson, V. W. \& Barden, R. E. (1969). Isocitrate dehydrogenase (TPN-specific) from pig heart. Methods in Enzymology 13, 30-33.

Copley, S. D. \& Crooks, G. P. (1992). Enzymic dehalogenation of 4-chlorobenzoyl coenzyme A in Acinetobacter sp. strain 4-CB1. Applied and Environmental Microbiology 58, 1385-1387.

Coughlan, M. P. (1980). Aldehyde oxidase, xanthine oxidase, and xanthine dehydrogenase: hydroxylases containing molybdenum, iron-sulfur, and flavin. In Molybdenum and Molybdenum-Containing Enzymes, pp. 119-185. Edited by M. P. Coughlan. Oxford: Pergamon Press.

Coughlan, M. P., Rajagopalan, K. V. \& Handler, P. (1969). The role of molybdenum in xanthine oxidase and related enzymes. Reactivity with cyanide, arsenite, and methanol. Journal of Biological Chemistry 244, 2658-2663.

Coughlan, M. P., Mehra, R. K., Barber, M. J. \& Siegel, L. M. (1984). Optical and electron paramagnetic resonance spectrophotometric studies on purine hydroxylase II from Aspergillus nidulans. Archives of Biochemistry and Biophysics 229, 311-316.

DE BEYER, A. \& LINGENS, F. (1993). Microbial metabolism of quinoline and related compounds. XVI. Quinaldine oxidoreductase from Arthrobacter spec. Rü 6la: a molybdenum-containing enzyme catalysing the hydroxylation at C-4 of the heterocycle. Biological Chemistry Hoppe-Seyler 374, 101-109.

ElliotT, J. J. \& Brewer, J. M. (1978). The inactivation of yeast enolase by 2,3-butanedione. Archives of Biochemistry and Biophysics 190, 351-357.

ENSIGN, J. C. \& RITTENBerg, S. C. (1965). The formation of a blue pigment in the bacterial oxidation of isonicotinic acid. Archiv für Mikrobiologie 51, 384-392.

FANSLER, B. \& LowENSTEIN, J. M. (1969). Aconitase from pig heart. Methods in Enzymology 13, 26-30.

FreudenberG, W., KoENIG, K. \& ANDReesen, J. R. (1988). Nicotine dehydrogenase from Anthrobacter oxydans: a molybdenum-containing hydroxylase. FEMS Microbiology Letters 52, 13-17.

Grant, D. J. W. \& AL-NaJJAR, T. R. (1976). Degradation of quinoline by a soil bacterium. Microbios 15, 177-189.

GUPTA, R. C. \& SHukLA, O. P. (1979a). Microbial transformation of isonicotinic acid hydrazide and isonicotinic acid by Sarcina sp. Journal of Bioscience 1, 223-234.

GUPTA, R. C. \& SHUKLA, O. P. (1979b). Isonicotinic and 2-hydroxyisonicotinic acid hydroxylases of Sarcina sp. Indian Journal of Biochemistry and Biophysics 16, 72-75.

HAMES, B. D. (1981). An introduction to polyacrylamide gel electrophoresis. In Gel Electrophoresis of Proteins. A Practical Approach, pp. 1-91. Edited by B. D. Hames \& D. Rickwood. Oxford: IRL Press.

Hettrich, D., Peschke, B., Tshisuaka, B. \& Lingens, F. (1991). Microbial metabolism of quinoline and related compounds. X. The molybdenum cofactors of quinoline oxidoreductases from Pseudomonas putida 86 and Rhodococcus spec. B1 and of xanthine dehydrogenase from Pseudomonas putida 86. Biological Chemistry Hoppe-Seyler 372, 513-517.

HIRSCHBERG, R. \& ENSIGN, J. C. (1971). Oxidation of nicotinic acid by a Bacillus species: source of oxygen atoms for the hydroxylation of nicotinic acid and 6-hydroxynicotinic acid. Journal of Bacteriology 108, 757-759.

Hughes, G. J., Frutiger, S., Paquet, N., Ravier, F., Pasquali, C., Sanchez, J.-C., James, R., Tissot, J.-D., BJellqvist, B. \& HochSTRASSER, D. F. (1992). Plasma protein map: an update by microsequencing. Electrophoresis 13, 707-714.

Hunt, A. L., Hughes, D. E. \& Lowenstern, J. M. (1958). The hydroxylation of nicotinic acid by Pseudomonas fuorescens. Biochemical Journal 69, 170-173.

JoHNSON, J. L. \& RAJAGOPALAN, K. V. (1982). Structural and metabolic relationship between the molybdenum cofactor and urothione. Proceedings of the National Academy of Sciences of the United States of America 79, 6856-6860.

JoHnson, J. L., Rajagopalan, K. V. \& MeYer, O. (1990). Isolation and characterization of a second molybdopterin dinucleotide molybdopterin cytosine dinucleotide. Archives of Biochemistry and Biophysics 283, 542-545. 
KoENIG, K. \& ANDREesen, J. R. (1990). Xanthine dehydrogenase and 2-furoyl-coenzyme A dehydrogenase from Pseudomonas putida Ful: two molybdenum-containing dehydrogenases of novel structural composition. Journal of Bacteriology 172, 5999-6009.

KozioL, J. (1971). Fluorometric analyses of riboflavin and its coenzymes. Methods in Enzymology 18 B, 253-285.

KRETZER, A. \& ANDREESEN, J. R. (1991). A new pathway for isonicotinate degradation by Mycobacterium sp. INA1. Journal of General Microbiology 137, 1073-1080.

LAEMMLI, U.K. (1970). Cleavage of structural proteins during the assembly of the head of bacteriophage T4. Nature, London 227, 680-685.

Lewis, N. J., Hurt, P., Sealy-Lewis, H. M. \& Scazzoccho, C. (1978). The genetic control of the molybdoflavoproteins in Aspergillus nidulans. IV. A comparison between purine hydroxylase I and II. European Journal of Biochemistry 91, 311-316.

LÖFfleR, F., MülleR, R. \& LiNGENS, F. (1992). Purification and properties of 4-halobenzoate-coenzyme A ligase from Pseudomonas sp. CBS3. Biological Chemistry Hoppe-Seyler 373, 1001-1007.

MARGolis, J. \& KeNRICK, K. G. (1967). Polyacrylamide gel-electrophoresis across a molecular sieve gradient. Nature, London 214, $1334-1336$.

MASSEY, V. \& EDMondson, D. (1970). On the mechanism of inactivation of xanthine oxidase by cyanide. Journal of Biological Chemistry 245, 6595-6598.

NAGEL, M. \& ANDReESEN, J. R. (1990). Purification and characterization of the molybdoenzymes nicotinate dehydrogenase and 6hydroxynicotinate dehydrogenase from Bacillus niacini. Archives of Microbiology 154, 605-613.

ORPIN, C. G., KNIGHT, M. \& Evans, W. C. (1972). The bacterial oxidation of N-methylisonicotinate, a photolytic product of paraquat. Biochemical Journal 127, 833-844.

Pereira, W. E., Rostad, C. E., Leiker, T. J., UpdegrafF, D. M. \& BENNETT, J. L. (1988). Microbial hydroxylation of quinoline in contaminated groundwater: evidence for incorporation of the oxygen atom of water. Applied and Environmental Microbiology 54, 827-829.
PesChKe, B. \& Lingens, F. (1991). Microbial metabolism of quinoline and related compounds. XII. Isolation and characterization of the quinoline oxidoreductase from Rhodococcus spec. B1 compared with the quinoline oxidoreductase from Pseudomonas putida 86. Biological Chemistry Hoppe-Seyler 372, 1081-1088.

RIENHÖFER, A. (1985). Strukturelle und immunologische Untersuchungen zur Xanthin - Dehydrogenase aus Butyribacterium barkeri, ein SelenoMolybdo- Eisen- Schwefel- Flavoprotein. Thesis, University of Göttingen.

Schach, S., Schwartz, G., Fetzner, S. \& Lingens, F. (1993). Microbial metabolism of quinoline and related compounds. XVII. Degradation of 3-methylquinoline by Comamonas testosteroni 63. Biological Chemistry Hoppe-Seyler 374, 175-181.

SCOPES, R. K. (1974). Measurement of protein by spectrophotometry at $205 \mathrm{~nm}$. Analytical Biochemistry 59, 277-282.

Sharma, M. L. \& ShUKLA, O. P. (1987). Microbial transformation of isoniazid and isonicotinic acid by soil bacteria. Biological Memoires 13, 1-17.

SHuKLA, O. P. (1984). Microbial transformation of pyridine derivatives. Journal of Scientific and Industrial Research 43, 98-116.

Sims, G. K. \& O'Loughin, E. J. (1989). Degradation of pyridines in the environment. Critical Reviews in Environmental Control 19, 309-340.

SINGH, R. P. \& SHUkLA, O. P. (1986). Isolation, characterization, and metabolic activities of Bacillus brevis degrading isonicotinic acid. Journal of Fermentation Technology 64, 109-117.

VAN DE BogarT, M. \& BeINERT, H. (1967). Micro methods for the quantitative determination of iron and copper in biological material. Analytical Biochemistry 20, 325-334.

Watson, G. K. \& CaIN, R. B. (1975). Microbial metabolism of the pyridine ring. Metabolic pathways of pyridine biodegradation by soil bacteria. Biochemical Journal 146, 157-172.

Wootton, J. C., Nicholson, R. E., Cock, J. M., Walters, D. E., BurKe, J. F., DOYLE, W. A. \& BRAY, R. C. (1991). Enzymes depending on the pterin molybdenum cofactor - sequence families, spectroscopic properties of molybdenum and possible cofactorbinding domains. Biochimica et Biophysica Acta 1057, 157-185. 